\title{
COMPLETE Y-SHAPED THROMBUS REMOVAL WITH A SIMPLE QUICKCAT THROMBECTOMY DEVICE IN PATIENTS WITH SUBACUTE STEMI AND INFLAMATORY BOWEL DISEASE
}

Nikola Jagic ${ }^{1}$, Vladimir Miloradovic ${ }^{1}$, Slobodanka Mitrovic ${ }^{2}$, Mladen Tasic ${ }^{1}$, Dejan Petrovic ${ }^{3}$

${ }^{1}$ Cardiac Catheterization Laboratory, Clinical Center Kragujevac

${ }^{2}$ Dept. of Pathology, Clinical Center Kragujevac

${ }^{3}$ Dept. of Nephrology, Clinical Center Kragujevac, Serbia

\author{
POTPUNA EKSTRAKCIJA "Y" TROMBA JEDNOSTAVNIM SISTEMOM \\ ZA TROMBEKTOMIJU KOD PACIJENTA SA SUBAKUTNIM INFARKTOM \\ MIOKARDA I ZAPALJENSIKIM OBOLJENJEM CREVA \\ Nikola Jagić ${ }^{1}$, Vladimir Miloradović ${ }^{1}$, Slobodanka Mitrović ${ }^{2}$, Mladen Tasić ${ }^{1}$, Dejan Petrović ${ }^{3}$ \\ ${ }^{1}$ Laboratorija za kateterizaciju srca, Klinički centar Kragujevac, Kragujevac \\ ${ }^{2}$ Služba za patologiju, Klinički centar Kragujevac, Kragujevac \\ ${ }^{3}$ Centar za nefrologiju i dijalizu, Klinički centar Kragujevac, Kragujevac, Srbija
}

Received / Primljen: 25. 07. 2011.

Accepted / Prihvaćen: 12. 08. 2011.

\begin{abstract}
:
Despite the controversial and inconsistent data in the literature, thrombectomy aspiration devices are increasingly used in everyday clinical practice. We present an interesting case report of an acute coronary syndrome patient who suffered from chronic inflammatory bowel disease. During diagnostic colonoscopy in a regional hospital, she developed ST elevation acute myocardial infarction (STEMI) with atrial fibrillation and heart failure. Treating this particular subpopulation of patients with such comorbidities presents challenges.
\end{abstract}

Key words: acute myocardial infarction, aspiration thrombectomy

\section{SAŽETAK:}

Uprkos kontraverznim i često nepotpunim literarnim podacima uređaj za aspiracionu trombektomiju se sve višse koristi u interventnoj kardiologiji tokom svakodnevne kliničke prakse. Predstavljamo interesantan prikaz slučaja akutnog koronarnog sindroma (AKS) kod pacijenta koji se lečio od hronične inflamatorne bolesti creva. Tokom dijagnostičke kolonoskopije u regionalnoj bolnici dolazi do razvoja infarkta miokarda sa ST elevacijom (STEMI), atrijalne fibrilacije i srčanog popuštanja. Interventni tretman kod ovakvih kompleksnih pacijenata uvek predstavlja izazov.

Ključne reči: akutni infarkt miokarda, aspiraciona trombektomija

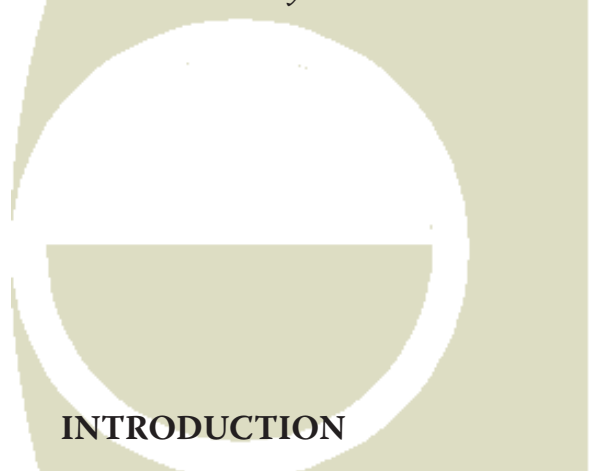

We report a case of a female patient who presented with acute coronary syndrome (ACS) during rectoscopy in a regional hospital due to suspicious inflammatory bowel disease. Due to exacerbation of inflammatory bowel disease, she had not received fibrinolytic therapy. She was transferred to our institution for coronary angiography, which revealed a transparent filling defect at the bifurcation of the first obtuse marginal branch (OM1), which is highly suggestive of an intra-arterial thrombus. Therefore, we decided to treat the OM1 branch with a QuickCat thrombectomy device. The aspirated material was a Y-shaped thrombus, which corresponded well to the angiographic image of the bifurcated thrombus.

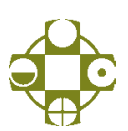

\section{Case report}

During a rectoscopy at a regional hospital, aA 66year-old woman presented with acute coronary syndrome (ACS) and acute heart failure (Killip class II) that manifested as STEMI at a,due to suspicious inflammatory bowel disease. She had history of a previous posterior myocardial infarction (MI) in 2004. Her ECG had showed posterolateral MI with atrial fibrillation. Due to exacerbation of the inflammatory bowel disease, she had not received fibrinolytic therapy. In the following days, she presented with prolonged anginal episodes, electrical instability, and heart failure. She had been defibrillated due to ventricular fibrillation (VF). Then, she was transferred to our institution for coronary angiography, which revealed borderline 


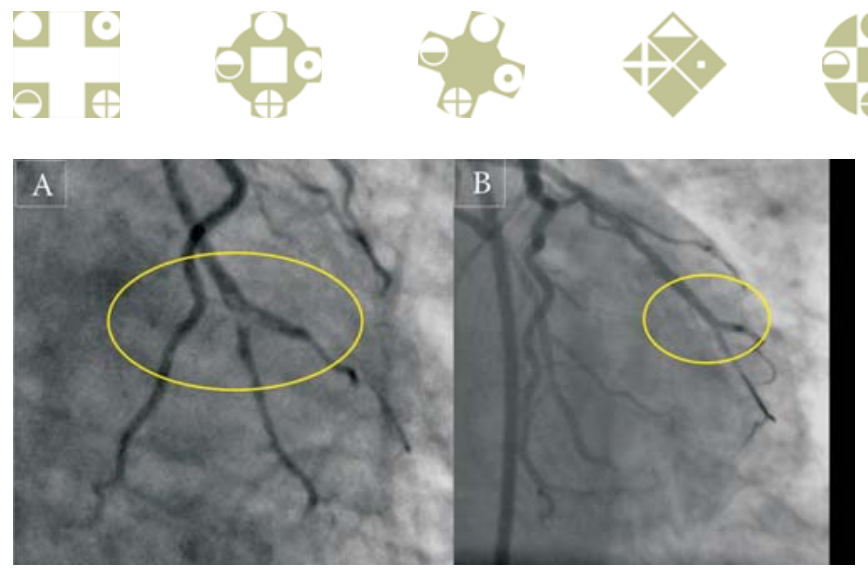

Fig. 1. Filling defect on the angiogram of the obtuse marginal artery (A) and its disappearance after thrombectomy (B).

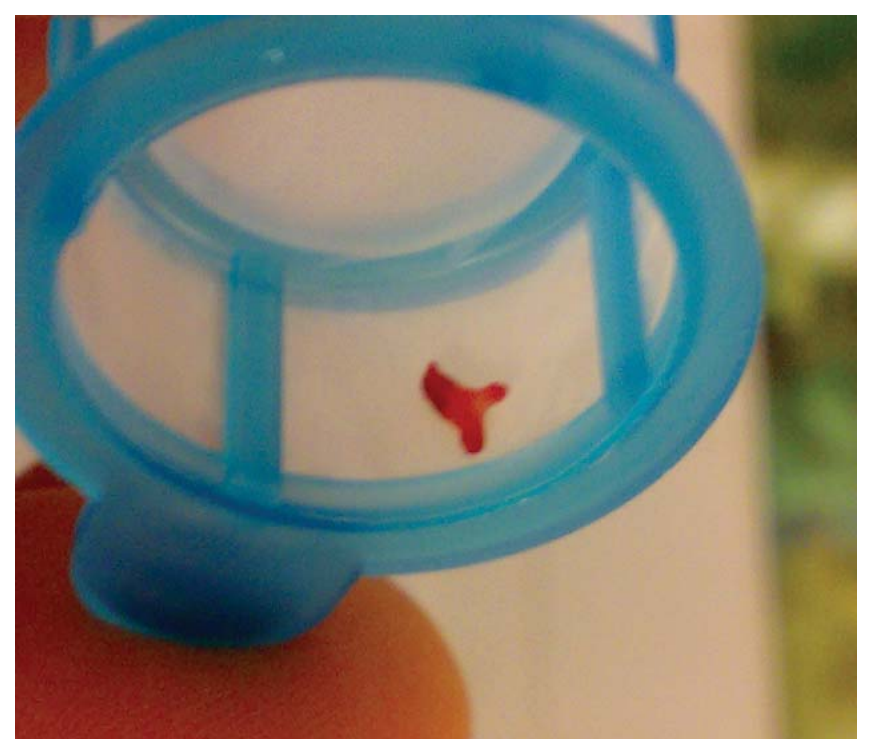

Fig. 2. Thrombus specimen

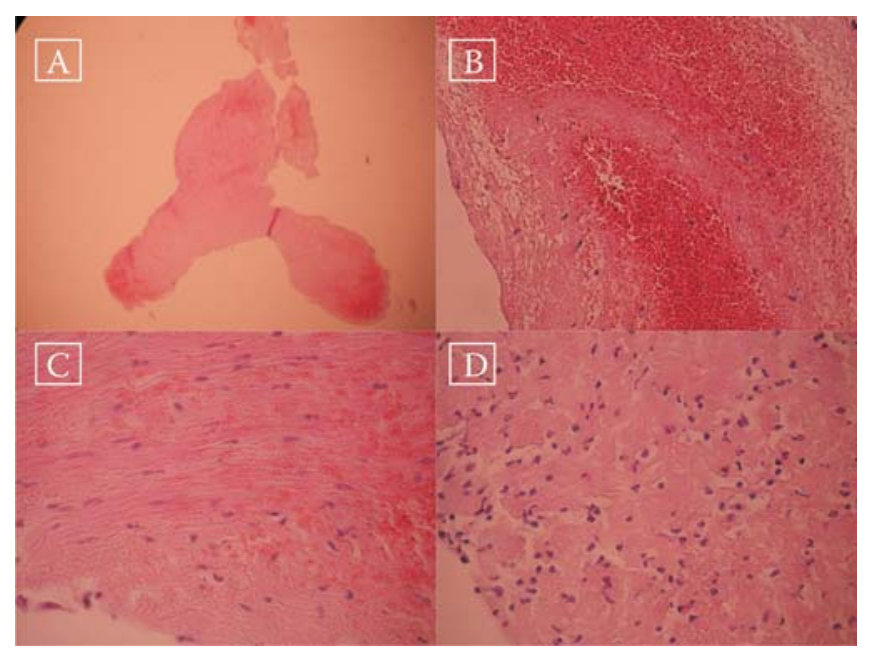

Fig. 3. Pathohistological characteristics of the aspirated thrombus

A - Macroscopic appearance of the Y-shaped specimen (40x magnification) B - A major part of the specimen was composed of an eosinophilic mass, with the border zone dominated by fibrin, erythrocytes, platelets and rare granulocytes (200x magnification)

C - Some parts had spindle cells (400x magnification)

D - The central parts were homogenised, revealing zones containing cytologically changed granulocytes (400x magnification) disease in the right coronary artery (RCA), a relatively disease-free left anterior descending artery (LAD), 95\% in mid-Cx, which suggested an old lesion, and a transparent filling defect at the bifurcation of first obtuse marginal branch (OM1), which is highly suggestive of an intra-arterial thrombus (Fig. 1A). Therefore, we decided to treat the OM1 branch first with a QuickCat thrombectomy device. The aspirated material was a Y-shaped thrombus that corresponded well to the angiographic image of the bifurcated thrombus (Fig. 2). Control angiography revealed no underlying stenotic lesions (Fig. 1B). The ST elevations in the lateral precordial leads and chest pain immediately resolved, so we decided to finish the procedure. Before discharge, an echo examination only revealed the hypokinetic posterior and lateral wall of the left ventricle, with moderate a global enlargement and an ejection fraction (EF) of approximately $50 \%$.

After 24-hour fixation in a $4 \%$ solution of formaldehyde, the aspirated thrombus was embedded in a paraffin cast. Five-micron slices (16 levels of cuts) were dyed by standard haematoxylin and eosin stain. Microscopic analysis revealed a mixed thrombus structure. A major part of the tissue was composed of an eosinophilic mass, with the border zone dominated by fibrin, erythrocytes, platelets and rare granulocytes. The central parts were homogenised, with zones in which cytologically changed granulocytes were appreciated, and some parts had spindle cells as well (Fig. 3).

The patient left the hospital in good overall condition, on double antiplatelet therapy, but after 4 weeks, she was again admitted to a local hospital due to acute heart failure. Her cardiac ultrasound examination showed normal inferior wall kinetics but posterior wall hypokinesis, and she was transferred to our centre again for a circumflex artery PCI procedure, which proceeded uneventfully. New episodes of atrial fibrillation were recognised, and anticoagulant therapy was added.

\section{DISCUSSION}

It has been reported that occlusive thrombi are composed of platelets, fibrin, erythrocytes and leucocytes [1], but they are predominantly composed of platelets in STEMI patients [2]. Murakami et al. classified thrombi according to thrombus age into three groups: fresh, lytic and organised. Fresh thrombi are one day old and are mainly constituted of fibrin, erythrocytes, platelets and intact granulocytes [3]. The second group, lytic thrombi, are between one and five days old and thrombi are characterised by zones of cytologically changed granulocytes [3]. The third group, organised thrombi, is characterised by the presence of spindle cells and; are older than five days. and They may,, comprise connective tissue and capillaries, but this is not required [3]. Thrombi with heterogeneous appearances of fresh, lytic and organised thrombi are always classified as older than five days. Therefore, the extracted 
mass in our case belongs to the last group. It is assumed that the heterogeneous nature of thrombi results from episodes of thrombus growth before the onset of occlusive thrombosis and clinical symptoms. Pathohistological analysis of thrombectomy samples from patients with acute myocardial infarction has shown that, in primary PCI, older thrombi were found in as many as $50 \%$ of patients [4]. They obstruct the infarct-related artery but embolise downstream micro-vessels, by mechanical fragmentation, which is either spontaneous or introduce via interventional procedures with eithera balloon or stent.

There are data [5] that confirm a high risk of thrombosis and markedly abnormal platelet function in patients with inflammatory bowel disease,. Both abnormalities are unrelated to the underlying bowel disease activity, and they imply that platelet hyperaggregation may be important in the development of thrombosis in such patients. The American Society for Gastrointestinal Endoscopy has published guidelines on the management of anticoagulants during endoscopy [6]. Their risk stratification model for endoscopic procedures was adopted to stratify the risk of haemorrhage as well asand certain clinical situations that could result in a high risk of thromboembolic complications. , Based on the study by Keeley et al., (2003) published in Lancet, we can assume that an interventional strategy is preferred to thrombolytic therapy in patients presenting with STEMI [7]. One can postulate about the importance of epicardial artery patency, the level of myocardial perfusion, reperfusion injuries and their predictive values on definite clinical outcomes [8]. There is, of course, the additional role of the microvascular response to thromboembolisation, including neurohumoural and vasospastic responses. We have to deal with more or less frequent, angiographically visible thrombotic material in the setting of STEMI. Disposing of this material is ideal. It is logical to expect that patients with the largest thrombus burden benefit most from thrombus extraction.

Thrombus-containing lesions result in seven-fold increases in hard endpoints, namely periprocedural myocardial infarction, emergency coronary artery bypass grafting (CABG) and death [9]. There is evidence that not all thrombi are visible on angiography - only one-third, according to angioscopic data [10]. Essentially, two general principles have motivated investigators and researchers in the medical community and in industry. The first is to evacuate thrombi out of the artery, and the second is to protect against further embolisation during interventional procedures. It seems that different extraction catheters and systems outnumber so-called protective devices, filters, occlusive balloons, etc. Despite all of those efforts, there is still no firm evidence from randomised, multicentred, clinical trials that favour the use of protective devices in STEMI over simple interventional approaches [11].

All of these methods showed better results in selected populations of AMI patients, particularly according to ST segment resolution rate or angiographic parameters, such as MBG (myocardial blush grade) or TIMI flow, compared to the conventional interventional approach. However, the 30-day mortality rate did not differ significantly.

Nevertheless, it seems logical that the device should be as user-friendly as possible, as well as simple and preferably cost-effective. At the same time, it must be safe, particularly smooth in delivery and not dissective or even perforative in nature. At the same time, the efficacy of such a device is usually measured using angiographic flow parameters, which act as surrogate markers for clinical efficacy, and clinical efficacy is truly the most important value that is measurable only through longer follow-up periods in large randomised trials.

Overall, there have been several meta-analyses published about the role of thrombectomy devices in primary or rescue PCI, and they are all concordant in their conclusions that there were no clinical benefits in terms of lower 30-day mortality rates. It ishould be stressed, however, that most complex and high-risk patients were excluded from these trials. Therefore, overall mortality would have been low anyway. New results from the TAPAS trial, which was the first major trial in 15 years, showed that mortality was altered by an adjunctive intervention [12].

Although mechanical removal of larger thrombus burdens before PCI reduces a source of potential embolisation, it does not prevent further aggregation during or shortly after the interventional procedure [12]. The vacuumed material is supposed to be macerated and dissolved during suction and collection in the drainage syringe; did not however, in our case, in which the thrombus sustained its macroscopic characteristics, despite a being suctioned through a narrow pathway. There are also endogenic fibrinolytics and anti-thrombotic agents that all contribute to the is lack of clear evidence of thrombi in collected blood samples from infarct-related arteries; yet, after catheter aspiration, we sometimes cannot appreciate thrombi in the vessel anymore. Soft material, i.e., red thrombi, is unlikely to be suitable for examination. However, white thrombi are somehow more difficult to aspirate through the relatively small lumen of aspiration catheters. The success of catheter aspiration is determined by the deliverability of the catheter, which depends on lesion localisation, vessel compliance, calcification and tortuosity.

This case shows the optimal performance of anthe available, easy-to-use, QuickCat device for a very quick and simple embolectomy procedure in the setting of acute myocardial infarction.

\section{REFERENCES:}

1. McLaughlin MG, Stone GW, Aymong E, et al. Prognostic utility of comparative methods for assessment of ST-segment resolution after primary angioplasty for acute myocardial infarction: the Controlled Abciximab and Device Investigation to Lower Late Angioplasty Complications (CADILLAC) trial. J Am Coll Cardiol 2004; 44: 1215-23. 
2. Kotani J, Nanto S, Mintz GS, et al. Plaque gruel of atheromatous coronary lesion may contribute to the no-reflow phenomenon in patients with acute coronary syndrome. Circulation 2002; 106: 1672-7.

3. Murakami T, Mizuno S, Takahashi Y, et al. Intracoronary aspiration thrombectomy for acute myocardial infarction. Am J Cardiol 1998; 82: 839-44.

4. Rittersma SZ, van der Wal AC, Koch KT, et al. Plaque instability frequently occurs days or weeks before occlusive coronary thrombosis. Circulation 2005; 111: 1160-5.

5. Webberley MJ, Hart MT, Melikian V. Thromboembolism in inflammatory bowel disease:role of platelets. Gut 1993; 34: 247-51.

6. Veitch AT, Baglin A. Gershlicket al. Guidelines for the management of anticoagulant and antiplatelet therapy in patients undergoing endoscopic procedures. Gut 2008; 57: 1322-9.

7. Keeley EC, Boura JA, Grines CL. Primary angioplasty versus intravenous thrombolytic therapy for acute myocardial infarction: A quantitative review of 23 randomised trials. Lancet 2003; 361: 13-20.
8. Karha J, Exaire JE, Rajagopal V, et al. Relation of myocardial perfusion to mortality after primary percutaneous coronary intervention. Am J Cardiol 2005; 95: 980-2.

9. Henriques JP, Zijlstra F, van 't Hof AW et al. Angiographic assessment of reperfusion in acute myocardial infarction by myocardial blush grade. Circulation 2003; 107: 2115-9.

10. Hoffmann R, Haager P, Arning J et al. Usefulness of myocardial blush grade early and late after primary coronary angioplasty for acute myocardial infarction in predicting left ventricular function. Am J Cardiol 2003; 92: 1015-9.

11. Gick M, Jander N, Bestehorn HP, et al. Randomized evaluation of the effects of filter-based distal protection on myocardial perfusion and infarct size after primary percutaneous catheter intervention in myocardial infarction with and without ST-segment elevation. Circulation 2005; 112: 1465-72.

12. Svilaas T, Vlaar PJ, van der Horst IC, et al. Thrombus aspiration during primary percutaneous coronary intervention. N Engl J Med 2008; 358: 557-67. 